\title{
Cyberbezpieczeństwo dzieci i młodzieży w prawie polskim
}

\author{
Cyber security of children and youth in Polish law
}

\section{Streszczenie:}

Niniejsza praca stanowi kontynuację dwóch wcześniejszych artykułów dotyczących cyberbezpieczeństwa najmłodszych w prawie międzynarodowym oraz europejskim. W artykule poruszone zostało zagadnienie cyberbezpieczeństwa dzieci i młodzieży na gruncie prawa polskiego. Autorzy rozpoczynają analizę od przedstawienia przepisów ustawy zasadniczej. Następnie przybliżone zostały zapisy prawa karnego materialnego i procedury karnej. Dalej autorzy przedstawiają ustawy ratyfikujące umowy międzynarodowe dotyczące zagadnienia bezpieczeństwa najmłodszych w cyberprzestrzeni. $\mathrm{W}$ podsumowaniu zawarte są wnioski płynące $\mathrm{z}$ analizy całościowej treści przepisów zarówno prawa międzynarodowego i europejskiego, jak i rozwiązań krajowych w tym zakresie.

Słowa kluczowe: cyberbezpieczeństwo, cyberprzestrzeń

\begin{abstract}
:
This work follows on from two previous articles on the cyber security of the youngest children in international and European law. The article discusses the issue of cyber security of children and youth on the basis of Polish law. The authors start their analysis with the presentation of the provisions of the constitution. Next, the provisions of substantive criminal law and criminal procedure are introduced.

The authors then present the laws ratifying the international agreements on the issue of the safety of the youngest children in cyberspace. The summary contains conclu-
\end{abstract}


Mateusz K. Maciejczuk et al. - Cyberbezpieczeństwo dzieci i młodzieży...

sions drawn from the analysis of the overall content of the regulations of both international and European law, as well as national solutions in the scope of the title.

Keywords: cybersecurity, cyberspace

\section{Konstytucja RP}

Konstytucja jako najważniejszy akt prawny w Rzeczpospolitej Polskiej nie dzieli bezpieczeństwa na różne kategorie ${ }^{1}$. Dlatego też próżno szukać w niej bezpośrednich odwołań do pojęcia cyberbezpieczeństwa. Przepisy zawarte w Konstytucji już w art. 5 odwołują się do pojęcia szeroko rozumianego bezpieczeństwa. W myśl tego przepisu „Rzeczpospolita Polska strzeże niepodległości i nienaruszalności swojego terytorium, zapewnia wolności i prawa człowieka i obywatela oraz bezpieczeństwo obywateli (...)". Obowiązek zapewnienia ochrony bezpieczeństwa obywateli, w tym w szczególności młodzieży i dzieci, spoczywa na wszystkich organach publicznych ${ }^{2}$. Jednym z najważniejszych przepisów Ustawy zasadniczej dotyczącym ochrony dzieci i młodzieży jest przepis zawarty $w$ art. 72. Nakłada on obowiązek ochrony praw dziecka na wszystkie instytucje i organy Rzeczypospolitej Polskiej. Zarazem uprawnia on wszystkie podmioty prawa do żądania od władz państwowych ochrony dziecka przed przemocą, okrucieństwem, wyzyskiem i demoralizacją. Ponadto powołuje do życia organ Rzecznika Praw Dziecka, który ma stać na straży ochrony praw i wolności dzieci i młodzieży.

Kolejnym ważnym przepisem dotyczącym bezpieczeństwa obywateli państwa jest art. 31 ust 3 Konstytucji, w myśl którego tylko ustawą można ograniczyć korzystanie z konstytucyjnych praw i wolności tylko $\mathrm{w}$ razie, gdy jest to $\mathrm{m}$. in. niezbędne $\mathrm{w}$ demokratycznym państwie dla jego bezpieczeństwa lub porządku publicznego albo wolności i praw innych osób, przy czym ograniczenia te nie mogą naruszać

\footnotetext{
${ }^{1}$ Konstytucja Rzeczypospolitej Polskiej z dnia 2 kwietnia 1997 r. (Dz. U. z 1997 r., nr 78 poz. 483 ze zm.).

2 E. Zatyka, [w:] E. M. Guzik-Makaruk (red.), Poczucie bezpieczeństwa obywateli w Polsce. Identyfikacja i przeciwdziałanie współczesnym zagrożeniom, LEX/el 2011.
} 
istoty wolności i praw obywatelskich. W celu zapewnienia szeroko rozumianego bezpieczeństwa państwo może ograniczyć prawa i wolności jednostki. Odzwierciedlenie tego przepisu zauważyć można przykładowo w ustawach zawierających czyny zabronione pod groźbą kary. Właśnie te akty prawne m. in. są prawną gwarancją bezpieczeństwa obywateli Rzeczypospolitej Polskiej, a w szczególności dzieci i młodzieży jako tych osób, które ze względu na swój wiek wymagają szczególnej ochrony prawnej. Akty prawne mające na celu zapewnienie bezpieczeństwa obywateli mogą istnieć w polskim systemie prawnym właśnie dzięki przepisom Ustawy zasadniczej, dlatego rola Konstytucji jest tak kluczowa, gdy mowa jest o bezpieczeństwie dzieci i młodzieży w cyberprzestrzeni.

Istotnym przepisem Konstytucji, który tylko pośrednio dotyka kwestii bezpieczeństwa dzieci i młodzieży, jest norma prawna $\mathrm{z}$ art. 45 . Przepis ten dotyczy możliwości wyłączenia jawności rozprawy ze względu m. in. na ochronę życia prywatnego strony. W przypadku małoletnich sądy często korzystają z tego prawa zagwarantowanego jednostce $\mathrm{w}$ Konstytucji, a skonkretyzowanego w ustawach, mając na uwadze nie tylko bezpieczeństwo dzieci i młodzieży dotkniętych np. cyberprzestępstwami, ale również ochronę ich prywatności.

\section{Prawo karne materialne}

Przepisy prawa karnego materialnego to podstawowe gwarancje bezpieczeństwa dzieci i młodzieży w cyberprzestrzeni. Przepisy te pełnią nie tylko funkcję chroniącą małoletnich przed przestępcami działającymi w sieci oraz za jej pomocą, ale również mają zastosowanie odstraszające potencjalnych sprawców cyberprzestępstw grożącą im surową karą. Definicja cyberprzestępczości wskazuje, iż jest ona zjawiskiem szerokim. W niniejszym podrozdziale omówione zostaną główne czyny zabronione, chroniące dzieci i młodzież. Kodeks karny33, mając na myśli dzieci i młodzież, posługuje się wielokrotnie niezdefi-

\footnotetext{
3 Ustawa Kodeks karny z dnia 6 czerwca 1997 r. (Dz.U. z 2016 r. poz. 1137 ze zm.).
} 
Mateusz K. Maciejczuk et al. - Cyberbezpieczeństwo dzieci i młodzieży...

niowanym pojęciem „małoletni”. Również doktryna nie wypracowała jednolitej terminologii ${ }^{4}$. Autor jest zdania, iż na potrzeby niniejszego podrozdziału należy uznać, że małoletnim jest osoba, która nie ukończyła 18 roku życia. Ustawodawca stosuje również pojęcie małoletniego poniżej lat 15 , a więc osoby, która w momencie czynu nie miała ukończonych 15 lat.

W pierwszej kolejności na uwagę zasługuje przestępstwo, które unormowane zostało przez ustawodawcę w art. 200a §1 kodeksu karnego. Przepis dodany został Ustawą nowelizującą kodeks karny z dnia 5 listopada 2009 r. ${ }^{5}$. i wszedł $\mathrm{w}$ życie 8 czerwca 2010 r. Powodem zmian, obok zobowiązań międzynarodowych, których stroną była Polska, jest fakt, iż zjawisko to rozpowszechniało się na masową skalę 6 . Sprawca tzw. przestępstwa groomingu, działając z zamiarem umyślnym kierunkowym w celu popełnienia przestępstwa zgwałcenia (art. 197 §2 pkt. 2) lub seksualnego wykorzystania małoletniego poniżej lat 15 (art. 200), jak również produkowania lub utrwalania treści pornograficznych za pośrednictwem systemu teleinformatycznego lub sieci telekomunikacyjnej, nawiązuje kontakt z małoletnim poniżej lat 15, zmierzając, za pomocą wprowadzenia jego osoby w błąd, wyzyskania błędu lub niezdolności do należytego pojmowania sytuacji albo przy użyciu groźby bezprawnej do spotkania z nim. Zgodnie z brzmieniem ustawy sprawca tego czynu zabronionego podlega karze pozbawienia wolności do lat 3.

W art. 200a §2 ustawodawca spenalizował zachowanie polegające na składaniu, przy wykorzystaniu systemu teleinformatycznego lub sieci telekomunikacyjnej, małoletniemu poniżej lat 15 propozycji obcowania płciowego, poddania się lub wykonania innej czynności seksualnej lub udziału w produkowaniu lub utrwalaniu treści porno-

\footnotetext{
${ }^{4}$ M. Kornak, Małoletni jako świadek w procesie karnym, LEX/el 2009.

5 Ustawa z dnia 5 listopada 2009 r. o zmianie ustawy - Kodeks karny, ustawy Kodeks postępowania karnego, ustawy - Kodeks karny wykonawczy, ustawy Kodeks karny skarbowy oraz niektórych innych ustaw (Dz. U. 2009, nr 206, poz. 1589).

6 V. Konarska-Wrzosek, Komentarz do art. 200a, [w:] V. Konarska-Wrzosek (red), Kodeks karny. Komentarz, LEX/el 2016.
} 
graficznych. Przy czym sprawca musi zmierzać do realizacji tej propozycji. Oba przestępstwa stypizowane w art. 200a to czynności mające na celu przygotowanie warunków do wyzyskania seksualnego dziec$\mathrm{ka}^{7}$. Ustawodawca przewidział za ten czyn karę grzywny, ograniczenia wolności albo pozbawienia wolności do lat 2 .

Przedmiotem ochrony przepisu z art. 200a $\$ 1$ i $§ 2$ k.k. jest prawidłowy rozwój fizyczny i psychiczny małoletnich ${ }^{8}$ oraz wolność seksualna małoletnich poniżej lat 15, osób, które ze względu na swój wiek i związaną z tym niedojrzałość psychiczną nie mogą podjąć świadomej decyzji co do własnej seksualności ${ }^{9}$.

Kolejnym chronologicznie i niezgodnym z prawem zachowaniem jest czyn $\mathrm{z}$ art. 200b k.k. Podobnie jak poprzedzające przestępstwo czyn ten został dodany nowelizacją z 5 listopada 2009 r. Strona przedmiotowa czynu polega na publicznym propagowaniu lub pochwalaniu zachowania o charakterze pedofilskim. Za powyższe przestępstwo kodeks karny przewiduje karę grzywny, ograniczenia wolności lub pozbawienia wolności do lat 2 . Przedmiotem ochrony tego przepisu jest obyczajność, która nie dopuszcza poglądu, że zachowania seksualne wobec dzieci można oceniać jako pozytywne ${ }^{10}$.

Ustawodawca spenalizował również zachowanie mające postać publicznego prezentowania treści pornograficznych w taki sposób, że może to narzucić ich odbiór osobie, która nie godzi się na to (art. 202 §1). Każdy, kto dopuszcza się takiego czynu, podlega karze grzywny, ograniczenia wolności lub pozbawienia wolności do lat 2. Indywidualnym przedmiotem ochrony jest ochrona osób, które świadomie nie chcą mieć kontaktu z treściami pornograficznymi ${ }^{11}$.

\footnotetext{
7 Ibidem.

8 J. Piórkowska-Flieger, Komentarz do art. 200a, [w:] T. Bojarski (red.), Kodeks karny. Komentarz, LEX/el 2016.

${ }_{9}^{9}$ M. Bielski, Komentarz do art. 200a, [w:] A. Zoll (red.), Kodeks karny. Część szczególna. Tom II, LEX/el 2013.

10 V. Konarska-Wrzosek, Komentarz do art. 200b, [w:] V. Konarska-Wrzosek (red), Kodeks karny. Komentarz, LEX/el 2016.

11 V. Konarska-Wrzosek, Komentarz do art. 202, [w:] V. Konarska-Wrzosek (red), Kodeks karny. Komentarz, LEX/el 2016.
} 
Mateusz K. Maciejczuk et al. - Cyberbezpieczeństwo dzieci i młodzieży...

Działanie mające postać produkowania w celu rozpowszechniania, utrwalania, sprowadzania, przechowywania, posiadania albo rozpowszechniania lub prezentowania treści pornograficznych z udziałem małoletniego albo treści pornograficznych związanych z prezentowaniem przemocy lub posługiwaniem się zwierzęciem (art. 202 §3) zostało zagrożone karą od 2 do 12 lat pozbawienia wolności. Czyn penalizuje zachowania związane z rozpowszechnianiem tzw. twardej pornografii (hardcoreporn/hard porno), czyli m. in. pornografii z udziałem osób małoletnich ${ }^{12}$.

Samo utrwalanie treści pornograficznych z udziałem małoletniego (art. 202 §4) zagrożone jest karą od roku do 10 lat pozbawienia wolności. Wartym zaznaczenia jest fakt, iż przez ponad 10 lat swojego istnienia przepis ten penalizował jedynie utrwalanie treści pornograficznych, w których uczestniczyła osoba małoletnia poniżej lat 15 . Dopiero Ustawa o zmianie ustawy kodeks karny oraz niektórych innych ustaw z dnia 4 kwietnia 2014 r. ${ }^{13}$ dokonała korekty przepisu, wykreślając ze znamion granicę lat 15 . Zatem obecnie granica ta wynosi 18 lat. Poprzez utrwalanie rozumieć można czynności polegające na przykład na robieniu zdjęć lub kręceniu filmów, na których osoby małoletnie dokonują czynności obiektywnie uznawanych za seksualne ${ }^{14}$.

Z kolei ten, kto przechowuje, posiada lub uzyskuje dostęp do treści pornograficznych z udziałem małoletniego (art. 202 §4a), musi liczyć się z karą pozbawienia wolności od 3 do 5 lat. Paragraf ten przeszedł podobną korektę, co przepis poprzedzający. Ustawodawca dokonał wykreślenia granicy wieku małoletniego. Obie korekty należy ocenić pozytywnie. Czynią one zadość opisanym w dalszej części umowom międzynarodowym, których Rzeczpospolita Polska jest stroną.

\footnotetext{
12 M. Berent, J. Bojarski, M. Filar, Komentarz do art. 202, [w:] M. Filar (red.), Kodeks karny. Komentarz, LEX/el 2016.

13 Ustawa z dnia 4 kwietnia 2014 r. o zmianie ustawy - Kodeks karny oraz niektórych innych ustaw (Dz. U. z 2014, poz. 538.).

14 V. Konarska-Wrzosek, Komentarz do art. 202 ..., op. cit.
} 
Identycznej karze, jak sprawca czynu z §4a, podlega ten, kto mając na celu zaspokojenie seksualne, uczestniczy w prezentacji treści pornograficznych z udziałem małoletniego (art. 202 §4c). Przepis ten jest stosunkowo nowy, wszedł w życie dopiero 25 kwietnia 2014 r. ${ }^{15}$. Warte zauważenia jest to, iż przepis ten nie kryminalizuje zachowania osoby, która samodzielnie, we własnym zakresie, wykorzystuje pornografię dziecięcą w celu zaspokojenia swojej dewiacji seksualnej16.

Tożsamy artykuł w §4b kryminalizuje zachowanie polegające na produkowaniu, rozpowszechnianiu, prezentowaniu, przechowywaniu lub posiadaniu treści pornograficznych przedstawiających wytworzony albo przetworzony wizerunek małoletniego uczestniczącego w czynności seksualnej. Jest to tzw. pornografia dziecięca pozorowana ${ }^{17}$. Sprawca, który dopuścił się takiego czynu, podlega karze grzywny, ograniczenia wolności albo pozbawienia wolności do lat 2 .

Przedmiotem ochrony czynów określonych w art. 202 §3-4c k.k. jest już bezpośrednio wolność seksualna osób małoletnich. Przepisy chronią małoletnich przed wykorzystaniem ich w treściach pornograficznych. Dodatkowo §3 przywołanego artykułu chroni również obyczajność sprzeciwiającą się pornografii dziecięcej18.

Jeżeli sprawca dopuścił się czynów określonych w §1-4c, sąd może orzec przepadek narzędzi lub innych przedmiotów, które służyły mu lub były przeznaczone do popełnienia przestępstw, nawet wtedy, gdy sprawca nie był ich właścicielem. Tak istotne naruszenie prawa własności wynika z normy ujętej w art. 202 §5 kodeksu karnego.

Wszystkie opisane czyny zabronione są przestępstwami publicznoskargowymi, a więc ścigane są przez wymiar sprawiedliwości z urzędu.

15 Ustawa o zmianie ustawy kodeks karny oraz niektórych innych ustaw z dnia 4 kwietnia 2014 r. (Dz. U. 2014, poz. 538).

16 V. Konarska-Wrzosek, Komentarz do art. 202..., op. cit.

17 N. Kłączynska, Komentarz do art. 202, [w:] J. Giezek (red.), Kodeks karny. Część szczególna. Komentarz, LEX/el 2014.

18 V. Konarska-Wrzosek, Komentarz do art. 202..., op. cit. 
Mateusz K. Maciejczuk et al. - Cyberbezpieczeństwo dzieci i młodzieży...

Powyżej opisane czyny zabronione to główne przestępstwa skierowane w sposób bezpośredni lub pośredni w dobra chronione osób małoletnich. Odnotowania wymaga fakt, iż dzieci i młodzież mogą paść ofiarą również innych przestępstw dokonywanych w cyberprzestrzeni lub za jej pomocą. Do przestępstw tych możemy zaliczyć: handel ludźmi (art. 189a), groźby karalne (art. 190) lub uporczywe nękanie (art. 190a §1), kradzież tożsamości (190a §2), zmuszanie do określonego zachowania (art. 191 §1), naruszenie intymności seksualnej (art. 191a), znęcanie się (art. 207), organizacja adopcji wbrew ustawie (art. 211a) oszustwa komputerowe (art. 287) oraz wiele innych, niewymienionych przestępstw, jeśli dokonane zostały na szkodę małoletniego, a czyn popełniony został w cyberprzestrzeni.

Sąd obok kary, wobec sprawcy w przypadkach wskazanych w ustawie może zastosować inne środki karne. Jeżeli sprawca dopuścił się czynu zabronionego przeciwko wolności seksualnej lub obyczajności na szkodę małoletniego, sąd może orzec zakaz zajmowania wszelkich lub tylko określonych stanowisk związanych z wychowaniem, edukacją, leczeniem małoletnich lub opieką nad nimi. Środek można zastosować na czas określony albo dożywotnio ${ }^{19}$ (art. 41§1a). W przypadku popełnienia czynu w warunkach skazanych poniżej, sąd może orzec również zakaz przebywania w określonych środowiskach lub miejscach, kontaktowania się z określonymi osobami, zbliżania się do określonych osób lub opuszczania określonego miejsca pobytu bez zgody sądu (art. 41a §1). Jeśli sprawca został skazany na karę pozbawienia wolności bez warunkowego zawieszenia jej wykonywania, sąd zobligowany jest do zastosowania takiego zakazu.

Przedawnienie karalności przestępstw na szkodę małoletniego zostało unormowane $\mathrm{w}$ przepisie $\mathrm{z}$ art. $101 \S 4$. W myśl tego przepisu, $\mathrm{w}$ razie popełnienia przez sprawcę przestępstwa przeciwko zdrowiu i życiu na szkodę małoletniego, którego górna granica przekracza 5 lat pozbawienia wolności albo popełnienia przestępstwa określonego

19 Wobec sprawcy, który dopuszcza się przestępstwa w warunkach określonych w 1a, sąd obligatoryjnie stosuje taki środek dożywotnio. 
w rozdziale 25 również na szkodę małoletniego, albo gdy treści pornograficzne obejmują udział małoletniego przedawnienie karalności przestępstwa nie może nastąpić przed ukończeniem przez pokrzywdzonego 30 roku życia ${ }^{20}$. Wartym odnotowania jest fakt, że kodeks karny przewiduje wyłączenie zatarcia skazania wobec sprawcy czynu przeciwko wolności seksualnej i obyczajności skazanego na karę pozbawienia wolności bez warunkowego zawieszenia, jeżeli przestępstwo zostało popełnione na szkodę małoletniego poniżej lat 15 (art. 106a).

\section{Procedura karna}

Kodeks postępowania karnego ${ }^{21}$ urzeczywistnia skuteczną realizację norm prawa karnego materialnego. Przepisy Ustawy m. in. gwarantują efektywne ściganie przestępców oraz chronią słuszny interes pokrzywdzonych czynami zabronionymi. Mając na uwadze zabezpieczenie interesu małoletnich, ustawodawca w przepisie z art. 51 k.p.k. postanowił, że w procesie karnym reprezentować go powinny osoby dorosłe, a więc przedstawiciele ustawowi albo osoba, pod której stałą opieką małoletni pozostaje. Aby ograniczyć do minimum negatywne konsekwencje psychiczne dzieci i młodzieży związane z postępowaniem karnym, wprowadzony został przepis z art. 185a k.p.k. ustanawiający odmienne reguły dotyczące przesłuchania pokrzywdzonego ${ }^{22}$. Małoletniego, który w chwili przesłuchania nie ukończył 15 lat oraz małoletniego, który ukończył ten wiek, lecz przesłuchanie go w innych warunkach mogłoby oddziałać negatywnie na jego psychikę, przesłuchuje się tylko raz ${ }^{23}$ i tylko wtedy, gdy jego depozycje mogłyby

20 Przepisy ogólne dotyczące przedawnienia stosuje się odpowiednio.

21 Ustawa Kodeks Postępowania Karnego z dnia 6 czerwca 1997 r. (Dz. U. 2016, poz. 1749 ze zm.).

22 Przestępstwa popełnione $\mathrm{z}$ użyciem przemocy lub groźby bezprawnej określone w rozdziałach XXIII, XXV i XXVI Kodeksu karnego.

${ }^{23}$ Wyjątek od tej zasady występuję wtedy, gdy wyjdą na jaw istotne okoliczności, których wyjaśnienie wymaga wtórnego przesłuchania lub na żądanie oskarżonego, który nie posiadał profesjonalnego obrońcy podczas pierwotnego przesłuchania. 
Mateusz K. Maciejczuk et al. - Cyberbezpieczeństwo dzieci i młodzieży...

mieć istotne znaczenie dla rozstrzygnięcia sprawy. Przesłuchanie przeprowadza sąd z udziałem biegłego psychologa ${ }^{24}$. W przypadku, gdy małoletni jest świadkiem przestępstwa, stosuje się przepis z art. 185b k.p.k.

Należy wspomnieć również o art. 607w k.p.k., który przewiduje wyłączenie zasady podwójnej karalności w przypadku, gdy państwo członkowskie Unii Europejskiej występuje o przekazanie osoby niebędącej obywatelem polskim, ściganej na podstawie europejskiego nakazu aresztowania, jeżeli sprawca popełnił $\operatorname{czyn}^{25} \mathrm{~m}$. in. przeciwko wolności seksualnej lub obyczajności na szkodę małoletniego.

Oddzielnym, jednak niezwykle ważnym zagadnieniem z punktu widzenia cyberbezpieczeństwa, m. in. dzieci i młodzieży, jest kwestia zbierania, utrwalania i wykorzystywania $\mathrm{w}$ postępowaniu przygotowawczym i sądowym dowodów, w tym dowodów cyfrowych (nazywanych również elektronicznymi). Polskie prawo nie wypracowało do tej pory definicji legalnej dowodów cyfrowych. W najprostszym ujęciu dowodem elektronicznym nazwać można każdą informacje zapisaną pod postacią cyfrową, mogącą mieć znaczenie jako dowód w sprawie.

W doktrynie dzieli się tę kategorię dowodów na statyczne i dynamiczne oraz na dowody rzeczowe i z dokumentów ${ }^{26}$. Dowodami cyfrowymi mogą być przykładowo: informacje zapisane na nośnikach pamięci, dokumenty elektroniczne (wiadomości email, pliki w postaci zdjęć oraz wideo), historia przeglądania stron internetowych, IP komputera, dane z serwerów czy dane geolokalizacyjne.

Brakuje w przepisach postępowania odróżnienia kwestii zabezpieczenia dowodów tradycyjnych od dowodów cyfrowych. W przypadku

${ }^{24} \mathrm{~W}$ przesłuchaniu uczestniczyć może prokurator, obrońca, pełnomocnik pokrzywdzonego oraz przedstawiciel ustawowy lub osoba, pod której opieką pozostaje małoletni tylko w przypadku, gdy nie ograniczy to swobody wypowiedzi przesłuchiwanego.

25 Czyn musi być zagrożony w państwie wydania nakazu karą minimum 3 lat pozbawienia wolności.

${ }^{26}$ A. Lach, Dowody cyfrowe $w$ postępowaniu karnym, wybrane zagadnienia praktyczne i teoretyczne, e-Biuletyn 2004, nr 2, CBKE, [dostęp: 9-9-2018]. 
zatrzymania rzeczy oraz przeszukania ${ }^{27}$, zgodnie z przepisem $\mathrm{z}$ art. 236a k.p.k., przepisy rozdziału 25 stosuje się odpowiednio do osoby, w której posiadaniu lub użytkowaniu znajduje się urządzenie zawierające dane informatyczne lub systemu informatycznego ${ }^{28}$. Podmioty publiczne i niepubliczne prowadzące działalność telekomunikacyjną zobowiązane są - na żądanie sądu lub prokuratora wyrażone w postanowieniu - do zabezpieczenia danych informatycznych, które przechowywane są w urządzeniach zawierających te dane na nośniku lub w systemie informatycznym ${ }^{29}$. Warto zauważyć, że zgodnie z art. $598 \mathrm{~g}$ k.p.k. sąd lub prokurator prowadzący sprawę w przypadku ustalenia, że dowód w sprawie znajduje się w innym państwie Unii Europejskiej, może wystąpić do państwa członkowskiego o wykonanie postanowienia o zatrzymaniu dowodów (w tym dowodów cyfrowych) ${ }^{30}$. Również w stosunku do kontroli poczty elektronicznej, zgodnie z art. 241 k.pk., stosuje się odpowiednio przepisy ogólne z rozdziału 26 k.p.k.

Wartym odnotowania jest również fakt, iż ustawodawca wspomnianą wcześniej nowelizacją ustawy kodeks karny oraz niektórych innych ustaw ${ }^{31}$ zmienił brzmienie przepisu z art. 19 Ustawy o Policji32, dodając do ustępu 1 podpunkt 3a. Przepis ten przewiduje, przy spełnieniu określonych warunków, możliwość zarządzenia kontroli operacyjnej, jeśli istnieje podejrzenie popełnienia przestępstwa przeciwko wolności seksualnej i obyczajności, gdy pokrzywdzonym jest mało-

27 Zgodnie z treścią przepisu z art. $143 \S 1$ pkt 6 k.p.k. z czynności przeszukania systemu informatycznego oraz zatrzymania rzeczy i danych informatycznych sporządza się protokół.

${ }^{28}$ Zakres dotyczy danych zapisanych na tym urządzeniu lub systemie albo na nośniku, w tym korespondencji przesyłanej za pomocą poczty elektronicznej.

${ }^{29}$ Dane należy przechować na czas określony w postanowieniu o zabezpieczeniu, jednak może on przekraczać 90 dni.

${ }^{30}$ Analogicznie, na podstawie art. $5899^{1}$ k.p.k., państwo członkowskie Unii Europejskiej może zwrócić się o wykonanie orzeczenia o zatrzymaniu dowodów.

31 Ustawa z dnia 4 kwietnia 2014 r. o zmianie ustawy..., op. cit.

32 Obwieszczenie Marszałka Sejmu Rzeczypospolitej Polskiej z dnia 7 października 2016 r. w sprawie ogłoszenia jednolitego tekstu ustawy o Policji (Dz. U. 2016, poz. 1782 t. j.). 
Mateusz K. Maciejczuk et al. - Cyberbezpieczeństwo dzieci i młodzieży...

letni albo gdy treści pornograficzne, o których mowa w art. 202 k.k. obejmują udział małoletniego.

\section{Oświadczenie rządowe z dnia 30 września 1991 r. o ratyfikacji w dniu 7 czerwca 1991 r. Konwencji o prawach dziecka}

Należy wskazać, że Rzeczypospolita Polska ratyfikowała w dniu 7 czerwca 1991 r. Konwencję o prawach dziecka sporządzoną przez Organizację Narodów Zjednoczonych. Zgodnie z oświadczeniem rządowym z dnia 30 września 1991 r. $^{33}$ weszła ona w życie w stosunku do Rzeczypospolitej Polskiej w dniu 7 lipca $1991 \mathrm{r}$.

Tekst konwencji przyjęty został przez Zgromadzenie Ogólne Narodów Zjednoczonych 20 listopada 1989 r. W związku faktem, iż technologie informacyjne nie były $\mathrm{w}$ tamtym okresie tak rozwinięte i popularne jak dziś, przepisy konwencji nie odnoszą się wprost do problemu bezpieczeństwa dzieci w cyberprzestrzeni. Zaznaczyć należy jednak, że Konwencja była jednym z pierwszych aktów prawa międzynarodowego kompleksowo regulującym prawa dzieci w świecie dorosłych, a przez doktrynę uznana została za światową konstytucję praw dziecka ${ }^{34}$. Dopiero protokół opcjonalny do Konwencji o prawach dziecka z dnia 25 maja 2000 r., podpisany przez Polskę 13 lutego 2000 r. zawierał zobowiązania stron do podjęcia działań mających przeciwdziałać zjawisku pornografii dziecięcej w Internecie ${ }^{35}$.

33 Oświadczenie Rządowe z dnia 30 września 1991 r. w sprawie ratyfikacji przez Rzeczpospolitą Polską Konwencji o prawach dziecka, przyjętej przez Zgromadzenie Ogólne Narodów Zjednoczonych dnia 20 listopada 1989 r. (Dz. U. 1991, nr 120, poz. 527).

${ }^{34}$ A. Łopatka, Dziecko. Jego prawa człowieka, Pol., Warszawa 2000, s. 19 i nast.

35 M. Gruchoła, Ochrona użytkowników Internetu w państwach unii europejskiej, Lublin 2012., s. 96. 


\section{Ustawa o ratyfikacji konwencji Rady Europy o cyberprzestępczości}

Powodem, dla którego państwa stowarzyszone w Radzie Europy podjęły się opracowania Konwencji, była wizja wspólnej polityki kryminalnej w obszarze cyberprzestrzeni. Konwencja Rady Europy została sporządzona w dniu 23 listopada 2001 r. w Budapeszcie. Państwa Rady Europy zobowiązały się w niej do podjęcia szeregu działań mających na celu przeciwdziałanie cyberprzestępczości i jej zwalczanie. Pomimo faktu, iż państwo polskie jest aktywnym uczestnikiem współpracy międzynarodowej mającej na celu eliminowanie przestępczości, Rzeczpospolita Polska ratyfikowała Konwencję dopiero 12 września 2014 r. ${ }^{36}$. Wskazać należy, że ratyfikacja powoduje sytuację, w której umowę międzynarodową wprowadza się do krajowego porządku prawnego. Pomijając powyższe, zaznaczyć trzeba, że sam proces implementacji Konwencji przez Rzeczpospolitą Polską rozpoczął się w 2004 r. i kontynuowany był przez kolejne lata ${ }^{37}$.

Omawiany akt prawny zawiera szereg przepisów dotyczących bezpieczeństwa w cyberprzestrzeni. Przepis z art. 9 zobowiązuje strony Konwencji do wprowadzenia przepisów z zakresu produkowania, oferowania, udostępniania, rozpowszechniania lub transmitowania, pozyskiwania oraz posiadania pornografii dziecięcej. Konwencja za osobę małoletnią uznaje jednostkę poniżej 18 roku życia. Daje jednak możliwość wprowadzenia przez stronę niższej granicy wieku, jednak nie może być ona niższa niż 16 lat. Przepis, który na pierwszy rzut oka wydaje się kontrowersyjny, uwzględnia różnorodność poszczególnych stron Konwencji umożliwiając im dostosowanie prawa do specyfiki systemu prawnego danego kraju. Ponadto konwencja zawiera szereg

36 Ustawa z dnia 12 września 2014 r. o ratyfikacji Konwencji Rady Europy o cyberprzestępczości, sporządzonej w Budapeszcie w dniu 23 listopada 2001 r. (Dz. U. 2014, poz. 1514).

37 A. Adamski, Konwencja Rady Europy o cyberprzestępczości i kwestia jej ratyfikacji przez Polskę, [w:] G. Szpor (red.), Internet. Ochrona wolności, własności i bezpieczeństwa, Warszawa 2011, s. 346. 
Mateusz K. Maciejczuk et al. - Cyberbezpieczeństwo dzieci i młodzieży...

norm prawnych zobowiązujących do wprowadzenia przepisów proceduralnych z zakresu gromadzenia i wykorzystywania dowodów cyfrowych. Zdaniem autora, twórcy Konwencji mieli na celu skuteczniejszą walkę z cyberprzestępcami i ujednolicenie procedur w krajach stowarzyszonych. Należy nie tracić z pola widzenia faktu, że przestępstwa związane z pornografią z udziałem osób małoletnich mają przeważnie wymiar transgraniczny. Cyberprzestępcy zajmujący się w szczególności rozpowszechnianiem, udostępnianiem oraz pozyskiwaniem pornografii dziecięcej chętnie korzystają z Internetu z uwagi na anonimowość, którą zapewnia sieć oraz jej potencjalnie nieograniczony zasięg. Mając na uwadze bezpieczeństwo dzieci i młodzieży, należy ocenić pozytywnie zarówno samą konwencję, jak i ustawę ratyfikującą ten akt.

\section{Ustawa o ratyfikacji Konwencji Rady Europy o ochronie dzieci przed seksualnym wykorzystaniem i niegodziwym traktowaniem w celach seksualnych}

Konwencja Rady Europy została sporządzona w dniu 25 października 2007 r. w Lanzarote. Jest ona pokłosiem Planu Działań przyjętym na Szczycie Głów Państw i Rządów Rady Europy w dniu 16-17 maja 2005 r. w Warszawie. Przedmiotową Konwencję Polska ratyfikowała ustawą z dnia 26 września $2014 \mathrm{r}^{38}$. Strony multilateralnej umowy międzynarodowej zauważyły, że seksualne wykorzystywanie dzieci przybrało w ostatnich latach alarmujący wymiar. Nagły wzrost problemu państwa upatrywały w zwiększeniu zainteresowania technologiami informacyjnymi zarówno małoletnich, jak i przestępców. Mając na uwadze powyższe, w celu zapobiegania seksualnemu wykorzystaniu dzieci i jego zwalczania, ochrony praw małoletnich będących ofiarami oraz promowania krajowej i międzynarodowej współpracy przeciwko temu zjawisku (art. 1) strony zobowiązały się podjąć konkretne

\footnotetext{
38 Ustawa z dnia 26 września 2014 r. o ratyfikacji Konwencji Rady Europy o ochronie dzieci przed seksualnym wykorzystywaniem i niegodziwym traktowaniem $\mathrm{w}$ celach seksualnych, sporządzonej $\mathrm{w}$ Lanzarote $\mathrm{w}$ dniu 25 października 2007 r. (Dz. U. z 2014, poz. 1623).
} 
działania ustawodawcze. Cały akt prawny dotyczy bezpośrednio bezpieczeństwa dzieci i młodzieży. Art. od 5 do 9 kładą nacisk na edukację i kampanie informacyjne, które uświadomiłyby zarówno dorosłym jak i dzieciom zagrożenia związane $m$. in. $\mathrm{z}$ bezpieczeństwem w cyberprzestrzeni osób poniżej osiemnastego roku życia. Umowa międzynarodowa zwraca uwagę również na pomoc ofiarom przestępstw, zobowiązując państwa do podjęcia w tym kierunku konkretnych działań wymienionych w Konwencji.

Rozdział VI przedmiotowego aktu to już zobowiązania stron dotyczące zmian w prawie karnym materialnym. Zobowiązuje on strony do wprowadzenia do porządku prawnego czynów zabronionych polegających na wykorzystaniu seksualnym małoletnich, prostytucji i pornografii dziecięcej, udziału małoletnich w prezentacjach pornograficznych oraz nagabywania dzieci za pośrednictwem Internetu w celu popełnienia powyższych przestępstw na jego szkodę, przy czym za propozycjami muszą iść faktyczne działania mające doprowadzić do spotkania z dzieckiem. Kolejny chronologicznie rozdział zawiera powinności stron do zmian w prawie procesowym tak, by jeszcze skuteczniej zabezpieczyć interes ofiar oraz efektywniej ścigać sprawców przestępstw na szkodę małoletnich.

Ratyfikowana Konwencja miała realny wpływ na polskie prawo karne materialne. Propozycje wypracowane przez państwa stowarzyszone w Radzie Europy doprowadziły do wprowadzenia nowych przepisów do polskiego porządku prawnego, które między innymi omówione zostały w poprzedniej części artykułu.

\section{Podsumowanie}

Odnosząc się do zapisów Ustawy zasadniczej, należy pamiętać, że Konstytucja Rzeczypospolitej Polskiej powstawała w czasach, w których technologie informacyjne nie były jeszcze tak rozwinięte i powszechne w użyciu. Obecnie praktycznie każdy przejaw życia społecznego dzieci i młodzieży związany jest z wykorzystaniem komputerów, 
Mateusz K. Maciejczuk et al. - Cyberbezpieczeństwo dzieci i młodzieży...

„smartfonów” i w konsekwencji Internetu. Należałoby zastanowić się, przy okazji zmian, nad wprowadzeniem do konstytucji przepisów, które kładłyby większy nacisk na bezpieczeństwo w cyberświecie nie tylko osób najmłodszych, ale również i starszych użytkowników Internetu. Zapisy takie byłyby poważnym argumentem za dalszym udoskonalaniem przepisów poszczególnych ustaw stojących na straży cyberbezpieczeństwa.

Wartym odnotowania jest pogląd przedstawicieli doktryny, którzy zwracają uwagę na fakt, iż polskie prawo karne nie jest do końca spójne z postanowieniami omawianej Konwencji Rady Europy o cyberprzestępczości ${ }^{39}$ i wymaga dalszych prac legislacyjnych. Problem przestępczości w cyberprzestrzeni wydaje się wymagać od społeczności międzynarodowej oraz rządów państw będących stronami umów międzynarodowych ${ }^{40}$ znacznie większego niż dotychczas poświęcenia mu uwagi, tak by wzmacniać ramy prawne oraz dokładnie i sprawnie implementować wypracowane rozwiązania. Ma to na celu znacznie szybsze reagowanie na pojawiające się cyberzagrożenia w sieci.

Czyny zabronione, które do tej pory były przestępstwami popełnianymi w realnym świecie, coraz częściej dokonywane są w cyberprzestrzeni. Powyższe dotyczy również przestępstw popełnianych na szkodę dzieci i młodzieży. Dynamika zmian w cyberprzestępczości determinuje konieczność zintensyfikowania prac nad przeciwdziałaniem i zwalczaniem tego zjawiska. Celowe byłoby nie tylko wprowadzenie programów edukacyjnych sygnalizowanych w przyjętych przez rząd polski Krajowych Ramach Polityki Cyberbezpieczeństwa Rzeczypospolitej Polskiej na lata 2017-2022, ale również zmiana prawa krajowego poprzez dostosowanie go do wiążących państwo polskie umów międzynarodowych oraz dostosowywanie przepisów do zmieniającej się rzeczywistości i penalizację zachowań, które do tej pory nie są zabronione (przykładowo cyberprzemoc). Niektórzy przedstawiciele doktryny postulują konieczność wprowadzenia do kodeksu

\footnotetext{
${ }^{39}$ A. Adamski, Konwencja Rady..., op. cit., s. 348 i nast.

40 Umów międzynarodowych dotyczących cyberprzestępczości.
} 
karnego odrębnego rozdziału poświęconego cyberprzestępstwom. Obecne tempo zmian może powodować sytuacje, w której wymagać będzie on ciągłej aktualizacji. Z drugiej strony zauważyć należy, że cyberprzestępczość to zjawisko o szerokim znaczeniu i nie wszystkie przepisy będą mogły znaleźć się w postulowanym rozdziale. Aczkolwiek wcielenie powyższej propozycji w życie stanowić może ważny krok w celu skuteczniejszego niż dotychczas zapewnienia bezpieczeństwa użytkowników cyberprzestrzeni, również tych najmłodszych. Przedmiotowy postulat jest wart uwagi przy następnym, szerszym przeglądzie polskich ustaw karnych.

Ochrona dzieci w cyberprzestrzeni to ciągły proces, gdyż katalog potencjalnych zagrożeń $w$ wirtualnym świecie jest otwarty i taki pozostanie. W związku z tym społeczność międzynarodowa obowiązana jest stale prowadzić prace mające na celu prewencję i ograniczanie skutków cybernaruszeń, gdyż prawo bardzo często jest spóźnione wobec aktualnych wyzwań. Skutkiem takiego działania może być przekazywanie impulsów legislacyjnych władzom poszczególnych państw w celu ujednolicania wzorca ochrony dzieci w cyberprzestrzeni. Społeczność międzynarodowa na arenie poszczególnych organizacji tworzy określone wzorce, ale to od państw zależy, czy finalnie cyberbezpieczeństwo dzieci zostanie zagwarantowane, gdyż to one implementują przepisy prawa międzynarodowego do krajowych porządków prawnych. Liczba dzieci korzystających z Internetu stale rośnie. Właśnie $w$ tym momencie powstaje pewien dysonans, gdyż użytkownikami Internetu są głównie osoby młode i w średnim wieku, a prawo tworzą bardzo często osoby w podeszłym wieku, dla których świat cyberprzestrzeni nie jest alternatywnym światem, a często czymś obcym ${ }^{41}$. W związku z tym warto wcielać w życie rekomendacje Rady Europy w kwestii współpracy ustawodawców z użytkownikami i dostawcami technologii w celu uzyskania efektu synergii. Na koniec

${ }^{41}$ M. Olchanowski, Bezpieczeństwo dzieci i młodzieży w cyberprzestrzeni na podstawie Krajowych Ram Polityki Cyberbezpieczeństwa Rzeczypospolitej Polskiej na lata 2017-2022, „Zeszyty Naukowe Zbliżenia Cywilizacyjne” 2017, t. XIII (3), s. 58 i nast. 
Mateusz K. Maciejczuk et al. - Cyberbezpieczeństwo dzieci i młodzieży...

warto pokusić się o odpowiedź na postawione we wstępie pierwszego artykułu pytanie: Czy zespół norm prawnych dotyczących bezpieczeństwa dzieci w cyberprzestrzeni można nazwać systemem, czy jest to raczej zbiór, zespół powiązanych tematycznie praw? Odpowiedzi nie można ograniczyć do znaków zero-jedynkowych. W ocenie autorów prawo dotyczące ochrony dzieci w cyberprzestrzeni obecnie kształtuje się w pewien system, ale jak wskazano jest to długofalowy proces, dlatego dalsza aktywność społeczności międzynarodowej w tej materii jest wskazana. Na zakończenie warto przytoczyć słowa wielkiego przyjaciela dzieci Janusza Korczaka, aby podsumować potrzebę ciągłej pracy na rzecz bezpieczeństwa dzieci: „Dzieci stanowią dużą odsetkę ludzkości, ludności, narodu, mieszkańców, współobywateli - stali towarzysze. Były, będą i są"42.

\section{Bibliografia:}

Adamski A., Konwencja Rady Europy o cyberprzestępczości i kwestia jej ratyfikacji przez Polskę, [w:] G. Szpor (red.), Internet. Ochrona wolności, własności i bezpieczeństwa, Wyd. C.H. Beck, Warszawa 2011.

Berent M., Bojarski M., Filar M., Komentarz do art. 202, [w:] M. Filar (red.), Kodeks karny. Komentarz, LEX/el 2016.

Bielski M., Komentarz do art. 200a, [w:] A. Zoll (red.), Kodeks karny. Część szczególna, tom II, LEX/el 2013.

Gruchoła M., Ochrona użytkowników Internetu w państwach unii europejskiej, Wyd. KUL, Lublin 2012.

Kłączynska N., Komentarz do art. 202, [w:] J. Giezek (red.), Kodeks karny. Część szczególna. Komentarz, LEX/el 2014.

Konarska-Wrzosek V., Kodeks karny. Komentarz, Komentarz do art. 200a, LEX/el 2016.

Korczak J., Prawo do szacunku, Wyd. Towarzystwo Wydawnicze w Warszawie, Warszawa 1929.

Kornak M., Małoletni jako świadek w procesie karnym, LEX/el 2009.

Lach A., Dowody cyfrowe w postępowaniu karnym, wybrane zagadnienia praktyczne i teoretyczne, e-Biuletyn 2004, $\mathrm{nr} 2$.

42 J. Korczak, Prawo do szacunku, Warszawa 1929. 
A. Łopatka, Dziecko. Jego prawa człowieka, Wyd. Prawnicze Iuris, Warszawa 2000.

Piórkowska-Flieger J., Komentarz do art. 200a, [w:] T. Bojarski (red.), Kodeks karny. Komentarz, LEX/el 2016.

Olchanowski M., Bezpieczeństwo dzieci i młodzieży w cyberprzestrzeni na podstawie Krajowych Ram Polityki Cyberbezpieczeństwa Rzeczypospolitej Polskiej na lata 2017-2022, „Zeszyty Naukowe Zbliżenia Cywilizacyjne” 2017, t. XIII (3).

Zatyka E., [w] M. Guzik-Makaruk (red.), Poczucie bezpieczeństwa obywateli w Polsce. Identyfikacja i przeciwdziałanie współczesnym zagrożeniom, LEX/el 2011. 